\title{
DEVELOPMENT AND CONSTRUCTION OF A CENTRIFUGE FOR MATERIALS PROCESSING IN HIGH ACCELERATIONS
}

\author{
Plínio Ivo Gama Tenório ' \\ Filipe Estevão Freitas ' \\ Pedro Tiago Barnabé Lomas ' \\ Irajá Newton Bandeira ' \\ Rafael Cardoso Toledo ' \\ Chen Ying An'
}

\begin{abstract}
Different accelerations, larger or smaller than Earth's gravity, can influence the materials solidification process. In order to study these effects in metallic alloys and semiconductors, a research centrifuge was developed at the Associated Laboratory of Sensors and Materials of the National Institute of Space Research (LABAS / INPE). The equipment aims to study the materials solidification both under high accelerations and also at the launching conditions of the VSB-30 sounding rocket, which reaches I 80 RPM (revolutions per minute) during upward flight. This launcher was used to perform microgravity experiments in previous laboratory work. This paper presents the design, the component fabrication and the centrifuge assembly.
\end{abstract}

Keywords: Centrifuge; Solidification; High gravity.

\section{DESENVOLVIMENTO E CONSTRUÇÃO DE UMA CENTRÍFUGA PARA SOLIDIFICAÇÃO DE MATERIAIS EM ALTAS ACELERAÇÕES}

\section{Resumo}

Diferentes acelerações, maiores ou menores que a gravidade terrestre, podem influenciar no processo de solidificação dos materiais. A fim de estudar esses efeitos em ligas metálicas e semicondutores, foi desenvolvida uma centrífuga para pesquisas, no Laboratório Associado de Sensores e Materiais do Instituto Nacional de Pesquisas Espaciais (LABAS/INPE). O equipamento tem como objetivo de estudar a solidificação de materiais em altas acelerações e também sob as condições simuladas do lançamento do foguete VSB-30, que atinge cerca de I 80 RPM (rotações por minuto) durante o voo ascendente. Este veículo foi utilizado pelo LABAS para realização de experimentos de solidificação de materiais em ambiente de microgravidade. $O$ trabalho tem por objetivo de apresentar o projeto, a fabricação de componentes e a montagem da centrífuga.

Palavras-chave: Centrifuga; Solidificação; Alta gravidade; Macrogravidade.

\section{INTRODUCTION}

The solidification of metals and their alloys depends on many different factors, in general, these terms are related to the processes of nucleation and growth; and both can be directly or indirectly affected by gravity force. The action of acceleration can change the heat and mass transfer during the material solidification process; and due to the action of Coriolis acceleration in the fluid (liquid material) that affects the stability of the thermal and constitutional flow [I-4].
These effects may change the microstructure and properties of the material $[4,5]$.

The study of materials solidified in centrifuges improves the understanding how the accelerations, bigger than the Earth's gravity, influence on materials processing. Large centrifuges are expensive and hardly available for crystal growth and solidification experiments [2,6-I I]. To overcome this difficulty, a small centrifuge was designed

'Laboratório Associado de Sensores e Materiais, Instituto Nacional de Pesquisas Espaciais - INPE, São José dos Campos, SP, Brasil.

E-mail: plinioivo@msn.com

*Versão revisada de trabalho apresentado na ABM Week 20I7, de 2 a 6 de outubro de 20I7, São Paulo, SP, Brasil. 
and built at Associated Laboratory of Sensors and Materials of the National Institute of Space Research (LABAS/INPE), which provides an acceleration ranging from I to 10 times the Earth gravity [II].

The objective of this work is to report the development and construction of LABAS/INPE centrifuge; and the two possible experiments that this equipment does.

\section{PROJECT AND MANUFACTURE OF THE CENTRIFUGE}

The development of the equipment was based on the concept developed by An et al. [2] and the requirements of the laboratory, as follows: (i) geometric and safety restrictions; (ii) demand for studies and research; and (iii) the availability of materials and manufacturing methods. The centrifuge design was divided in two applications: materials solidification and simulation of sounding rocket rotation.

The centrifuge is composed of a metal structure in which the rotating system, the transmission joint with rotary electric contact, and the arm metal are installed; this set is called a base and is common for both applications, Figure Ia.

The metal structure was designed in CAD software, and manufactured with welded ASTM A36 steel bars; before the fabrication, was simulated per finite elements (Figure Ib) the deformation supported by the structure in the local of greatest request, the results presented deformation the $10^{-2}$ order, with safety factor 1.5 , so the design was considered adequate for the application [12].

The centrifuge rotating system provides the necessary condition to have accelerations bigger than the Earth's gravity; the W22 electric motor (220/380 V, I HP) and the CFW-08 frequency inverter, manufactured by WEG ${ }^{\circledR}[13,14]$, were used, due to better accuracy in speed control, number of poles and to low levels of noise and vibration.
The centrifuge transmission joint with rotary electric contact has the objective to connecting the motor and the arm, transmitting the rotation, with minimum loss. Other point is, accomplish the electrical contact with the experiment fixed on the arm. This machined part is subjected mainly a compressive load. Due to this, was chosen ductile materials for the parts, aluminum AA 635I-T6 and PVC (polyvinyl chloride), the second used only for electrical insulation of the contact rings, without performing any structural function $[2, \mathrm{II}]$.

The arm is manufactured with a rectangular bar aluminum AA 635I-T6 and has dimensions specific to each application.

\section{EXPERIMENTS CONFIGURATIONS}

\section{I Materials Solidification in High Acceleration}

The equipment used in this experiment consists in a resistive electrical furnace fixed to $1.5 \mathrm{~m}$ aluminum arm, for this, it is used a steel hinge, which has two bearings and supports a weight up to $45 \mathrm{~kg}$. Due to the positioning of the furnace, displaced from motor shaft, a weight balance of arm was made, steel counterweights were installed on the other side the arm (opposed the furnace), Figure $2 \mathrm{a}$. This set-up of fixing the furnace (Figure $2 b$ ) allows to measure the gravity level on the solidification sample because the furnace is automatically aligned to the resultant force during the rotation [ $\mathrm{II}$.

The drawing of the furnace is shown on Figure 3a. It comprises a tubular furnace made of stainless steel, with $110 \mathrm{~mm}$ of diameter, $200 \mathrm{~mm}$ of length and weighting $9.6 \mathrm{~kg}$. The processing chamber of the materials is a ceramic tube with $20 \mathrm{~mm}$ diameter, running through the whole furnace length; the upper $120 \mathrm{~mm}$ part of the ceramic tube is evolved by a shielded nickel-chromium resistance $(28 \Omega-300 \mathrm{~W})$, the space
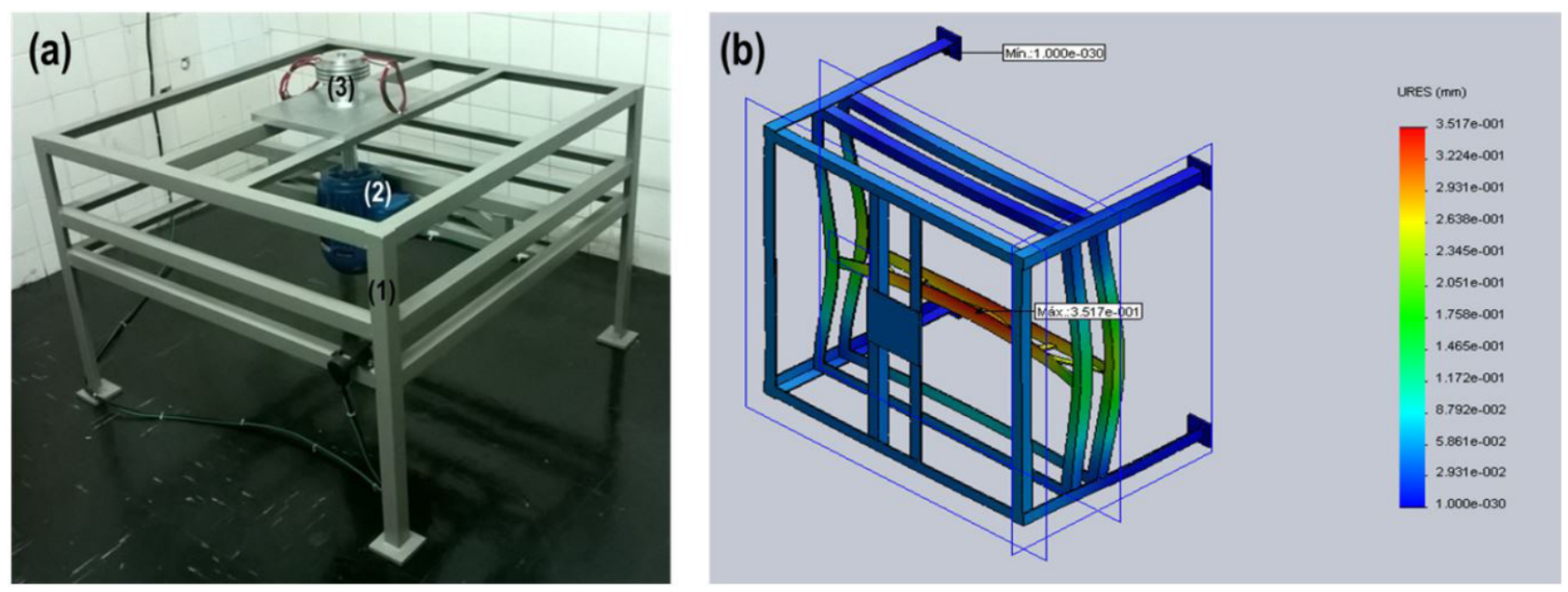

Figure I. (a) Description of the base centrifuge: (I) metal structure, (2) rotating system, and (3) transmission joint with rotary electric contact; and (b) Simulation in finite elements. 

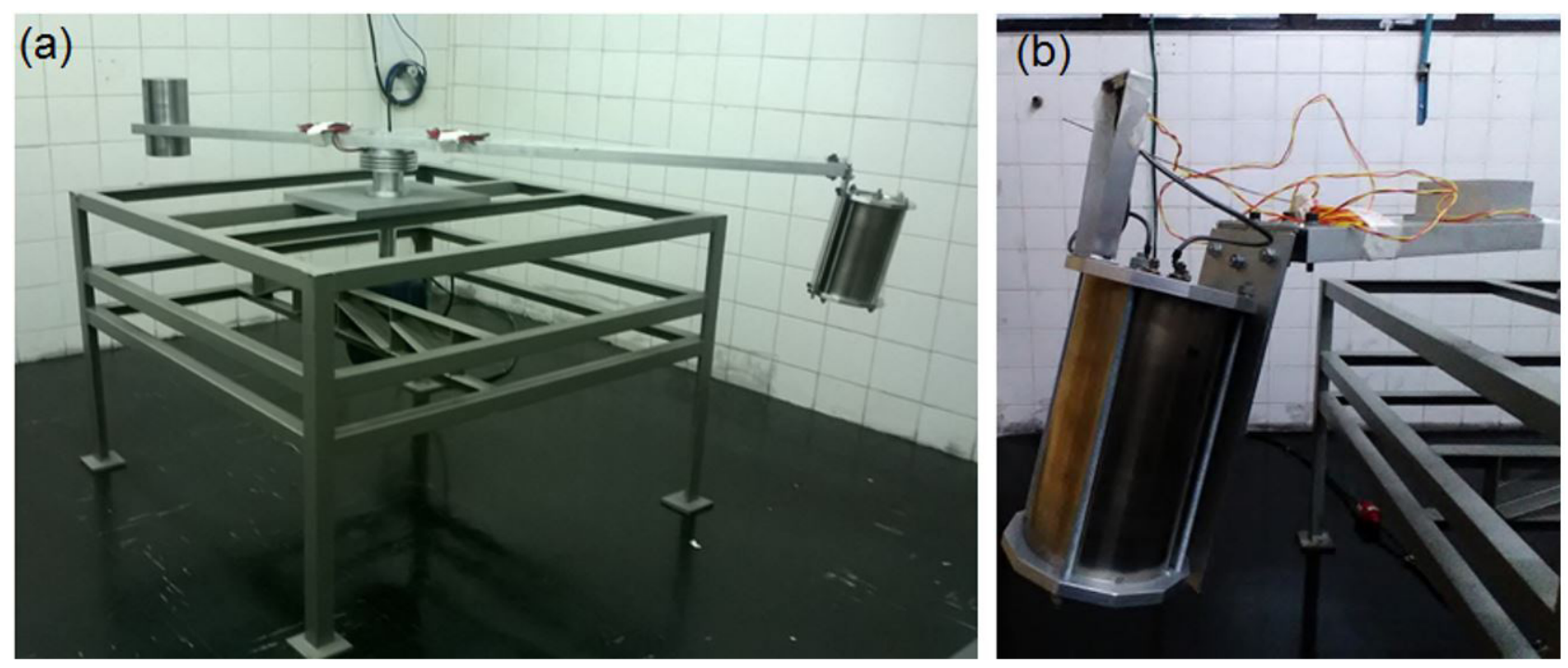

Figure 2. (a) High acceleration test equipment; (b) the furnace is attached to the aluminum arm by a steel hinge.

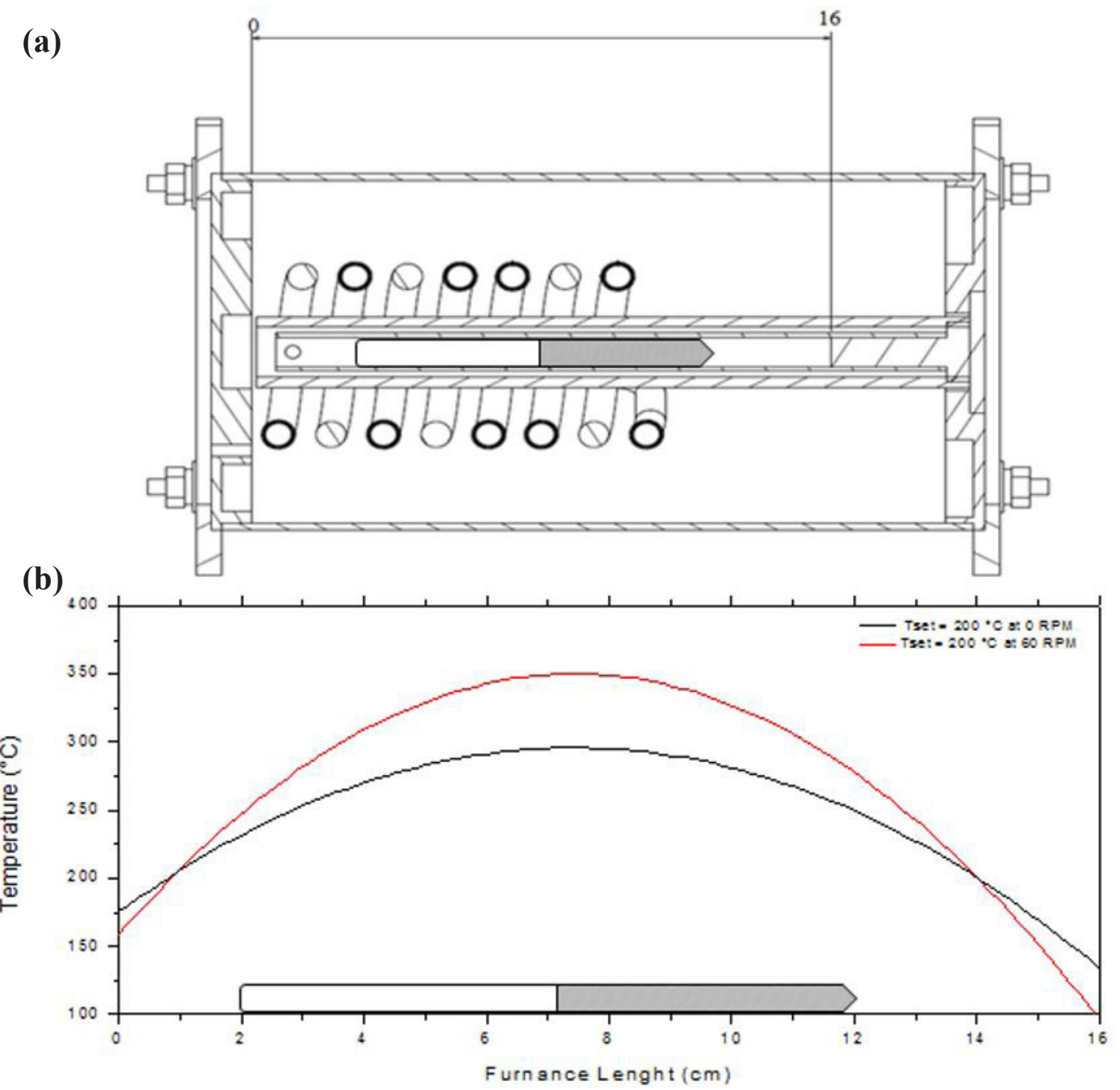

Figure 3. (a) Drawing of the furnace; and (b) the temperature profile of the furnace in the two conditions imposed. 
between the walls of the tube is filled with quartz fiber which is employed as thermal insulation. This furnace was designed to reach temperatures up to $1000^{\circ} \mathrm{C}$. It is connected to a power module (NOVUS - model SSR-4840) which is controlled by a temperature controller (NOVUS - model N2000).

The Figure $3 \mathrm{~b}$ show the temperature profile of furnace for two situations: (i) static, and (ii) with rotation of 60 RPM; with control temperature (Tset) of $200^{\circ} \mathrm{C}$ and $300^{\circ} \mathrm{C}$. It is possible to observe in this graph the thermal stability of the furnace in the two conditions imposed.

\subsection{Simulation of Rotations During the Upward Flight of VSB-30}

This experiment aims to investigate if the rotations during the upward flight of the VSB-30 sounding rocket (I 80 RPM) influenced the solidification process of the eutectic alloys tested during the flight the Maracati II Mission [15- 18],

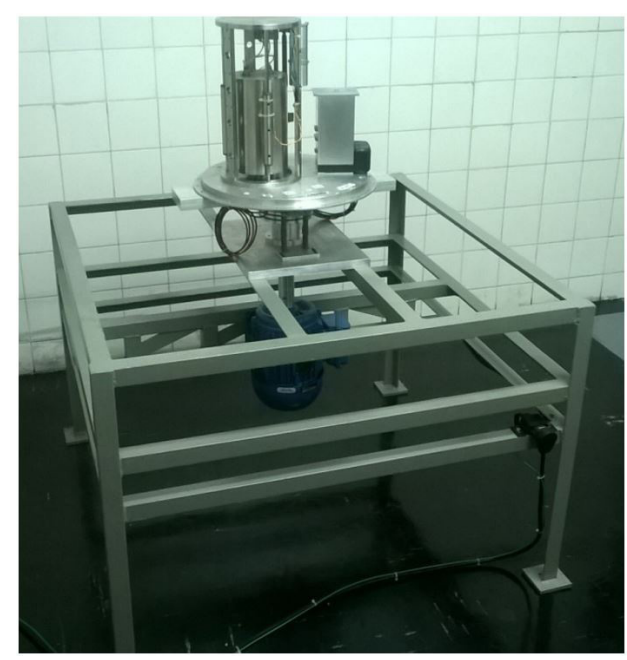

Figure 4. Equipment for the simulation of rotations. which is part of the Brazilian Space Agency (AEB) microgravity program.

In the rotation simulations, the furnace system developed by An et al. was fixed on the same platform used during the VSB-30 flight, and was fixed in an aluminum arm of $0.5 \mathrm{~m}$ in the centrifuge base, Figure 4 . In this configuration the centrifuge generate rotations conditions up to I80 RPM (maximum rotation of 1000 RPM) during the solidification process, this is the rotation the VSB-30 in the upward flight; all experiments parameters will be the same as used during Maracati II Mission [16-18].

\section{CONCLUSION}

The centrifuge for materials processing in high accelerations, provided by LABAS/INPE, was developed for complement the studies of the influence of gravity on the solidification of metallic alloys, is ready to be used by the group or other researchers that are interested in processing materials in macrogravity environments. Whit this, the laboratory is a few one to have this technology available to the researchers in Brazil. As for the scientific findings, the group started the comparison the alloys grown (PbSn and $\mathrm{PbTe}$ eutectics alloys) in macrogravity, microgravity and normal gravity, the results will be published elsewhere.

\section{Acknowledgements}

The authors are grateful to the Brazilian National Council for Scientific and Technological Development (CNPq) and the Coordination for the Improvement of Higher Education Personnel (CAPES) for the financial support.

\section{REFERENCES}

I Walter HU, editor. Fluid sciences and materials science in space: a european perspective. Berlin: Springer; 1987.

2 Chen YA, Russo LC, Ribeiro MF, Bandeira IN. A low cost centrifuge for materials processing in high gravity. In: Regel LL, Wilcox WR. Centrifugal materials processing. New York: Plenum Press; 1997. p. I I5- II9.

3 Dhindaw BK. Solidification under microgravity. Sadhana. 200 I;26(I-2):59-69.

4 Chirita G, Soares D, Silva FS. Advantages of the centrifugal casting technique for the production of structural components with Al-Si alloys. Materials \& Design. 2008;29(I):20-27.

5 Kurz W, Fisher DJ. Fundamental of solidification. 4th. ed. Switzerland: Trans Tech Publications; 1998. 305 p.

6 Bárczy P, Solyóm J, Regel L. Solidification of $\mathrm{Al}-\mathrm{Al} 3 \mathrm{Ni}(\mathrm{Cu})$ eutectics at high gravity. Journal of Crystal Growth. 1992; I 19(1-2): I60-166.

7 Regel LL, Wilcox WR. Materials processing in high gravity. New York: Plenum Press; 1994.

8 Friedrich J, Müller G. Convection in crystal growth under high gravity on a centrifuge. In: Regel LL, Wilcox WR. Centrifugal materials processing. New York: Plenum Press; 1997. p. 17-28. 
9 Limin J, Zhimin L, Daming X, Jingjie G. Effects of centrifugal forces and casting modulus on structures and mechanical properties of Ti-6Al-4V Alloy. Rare Metal Materials and Engineering. 20I6; 45(3):58I-587.

10 Freitas FE, Toledo RC, Poli AKS, An CY, Bandeira IN. The influence of high gravity in PbSn eutectic alloy. In: Anais do $21^{\circ}$ Congresso Brasileiro de Engenharia e Ciência dos Materiais; 2014 Novembro 9-13; Cuiabá, Brasil. São Paulo: Metallum; 20I4. p. 655I-6557.

II Tenório PIG, Toledo RC, Freitas FE, Fumachi EF, Bandeira IN, An CY. Desenvolvimento de uma centrífuga para solidificação de ligas eutéticas em macrogravidade. In: Anais do VI Workshop em Engenharia e Tecnologia Espaciais; 2015 Agosto 19-20; São José dos Campos, Brasil. São José dos Campos: INPE; 2015.

12 Ferro RM, Ferreira WG, Calenzani AFG. Estado da arte: análise dinâmica de estruturas de aço suportes de máquinas rotativas. In: Anais do XI Simpósio de Mecânica Computacional; II Encontro Mineiro de Modelagem Computacional; $20 I 4$ Maio 28-30; Juiz de Fora, Brasil. Juiz de Fora: Universidade Federal de Juiz de Fora; 2014.

13 WEG. W22 motor elétrico trifásico - catálogo técnico mercado brasileiro. Jaraguá do Sul: WEG S.A.; 2016.

14 WEG. Manual do usuário WEG: inversor de frequência CFW-08. Jaraguá do Sul: WEG S.A.; 2009. 213 p.

I5 An CY, Boschetti C, Ribeiro MF, Toledo RC, Freitas FE, Bandeira IN. Performance of a solidification furnace developed for sounding rockets. Microgravity Science and Technology. 20I I;23(4):427-432.

16 An CY, Boschetti C, Ribeiro MF, Toledo RC, Freitas FE, Castilho FF et al. Solidification furnace for microgravity experiments on sounding rockets. Journal of Aerospace Technology and Management. 2012;4:237-240.

17 Toledo RC. Estudo da solidificação de ligas metálicas eutéticas em ambiente de microgravidade [tese]. São José dos Campos: INPE; 2013.

I8 An CY, Toledo RC, Boschetti C, Ribeiro FM, Bandeira IN. Solidification of lead tin and lead telluride eutectic alloys in microgravity. Microgravity Science and Technology. 20I4;25(5):267-273. http://dx.doi.org/I0. I007/s I 22 I7-0I39348-7.

Received: 20 Nov. 2017

Accepted: 26 Jul. 2018 